\title{
Trade in Solid Wood Products \\ - A Canadian Perspective
}

by

R.V. Smith

\section{Introduction}

Generally the Canadian solid wood products industry has fallen on hard times. We are faced with a huge, production overcapacity in North America. This results from investment in the period 1965-80, which was attracted to the industry by rising real prices and the view, espoused by many distinguished, supply-side pundits, that the world was running out of wood. The reality of the 1980's has pretty well extinguished that view and with it the hopes of some in industry, that it was just a matter of waiting for the economy to turn around and business would boom again.

At the same time as overcapacity struck prices down, the Canadian and US dollars were rising in value against overseas currencies (because of our high real interest rates, fuelled by government overspending). This made our exports too expensive for many of our traditional customers, who were themselves mired in recession.

Our main salvation as an industry was the weakening of the Canadian dollar against the US dollar. This permitted Canada to sell lumber into the U.S, albeit with little profit, but at better returns than could be obtained in other markets.

This paper looks at our trade history in solid wood products, briefly examines some of the factors that will affect future trade patterns, reaches some conclusions and makes recommendations, which, if implemented, will permit the industry to flourish again. We also touch on the relationship between today's forest management and wood products trade in the 21st century: the raison d'être for this National Forest Congress.

\section{Current Trade Pattern}

The relative volumes of the main product groups are shown in Figure 1. Lumber is much the largest, constituting more than $95 \%$ of all solid wood products.

The value of these products is shown in Figure 2. Again the lumber category is much the largest but the common construction lumber is less valuable per cubic metre than the other products, which have more value added.

Note that we have not separated hardwood products from softwoods. In lumber, plywood and particle-board, the hardwood portion is insignfiicant at the national level. In waferboard, the product is almost exclusively manufactured from hardwoods.

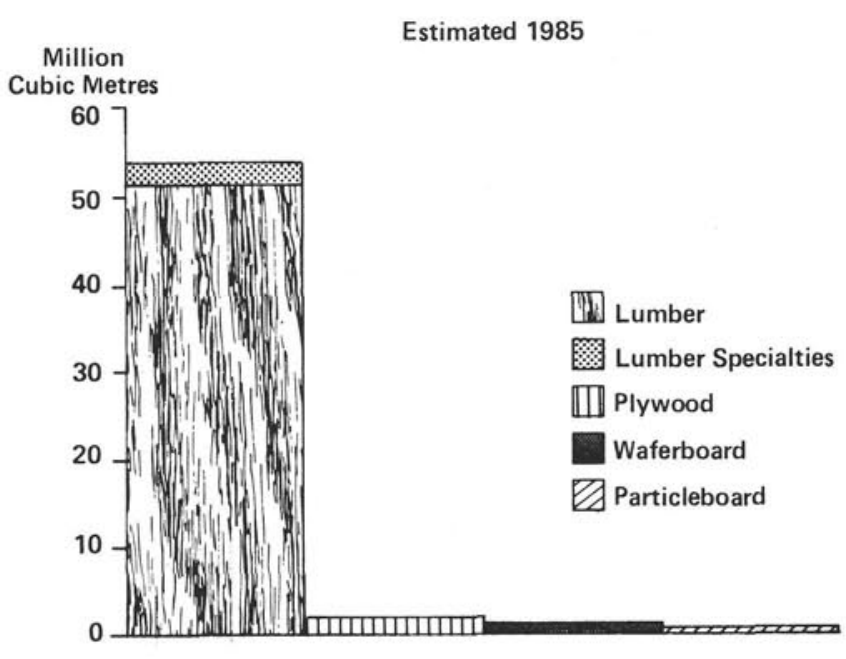

Figure 1. Volume of Canadian Solid Wood Shipments, estimated 1985.

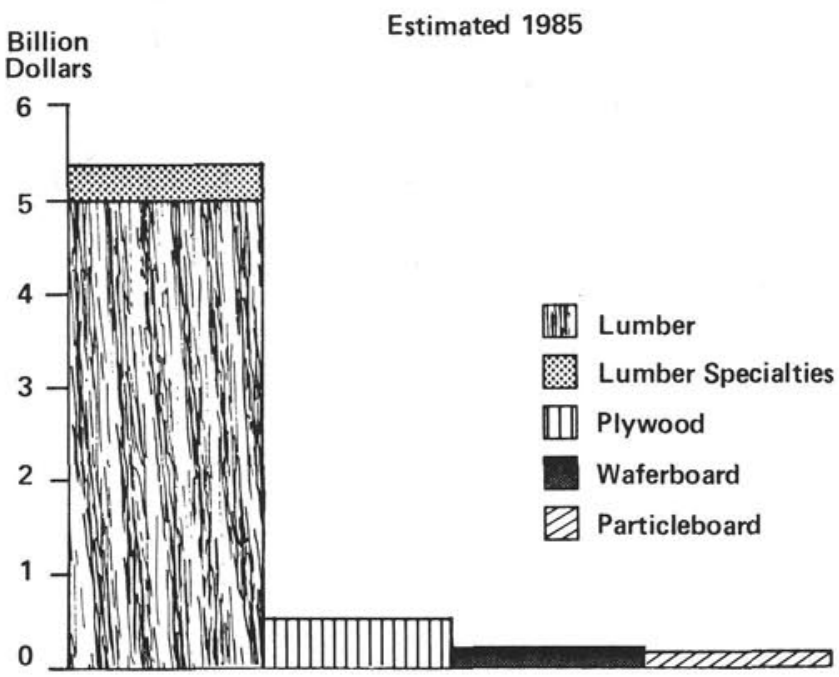

Figure 2. Value of Canadian Solid Wood Shipments, estimated 1985. 
The distribution of Canadian lumber is shown in Figure 3 at five-year intervals 1970-85.

From this we can see:

- the domestic market has grown steadily with production and has remained the second largest destination for our lumber;

- the US market has rmained the most important destination for Canadian lumber and has gained in importance steadily to 1985 when it received $65 \%$ of production and $85 \%$ of the exported volume;

- subject to fluctuations in local economies and exchange rates, Japan and Europe, while important markets, have not absorbed large proportions of our total lumber production, but they do take a high percentage of certain product sub-groups at higher prices than alternative, domestic markets; and

- other destinations take a very small proportion of the total volume produced.

The distribution of Canadian plywood is shown in Figure 4. Note that the scale is different from that for lumber and the distribution pattern is also different:

- about $80 \%$ of plywood is sold in Canada;

- the second and only other major market, is Europe; and

- almost no plywood crosses the US border either way, due to high tariffs.

Waferboard/OSB distribution is not illustrated. About $50 \%$ of our production is used domestically. The balance goes to the US over a relatively small tariff barrier.

\section{Trends in Trade}

Wood as a building material offers several advantages over other products:

- a high strength/weight ratio

- it is easily worked and fastened

- a low labour component in construction

This last may be a disadvantage in countries where labour is both cheap and abundant and wood is relatively expensive.

The cost of wood as a building material, which will be reflected in its consumption pattern, both in the form of wood used and vis a vis other building materials, is dictated by the availability of forest, the characteristics of the various tree species and the degree of modification, using technology, labour and energy by which it is transformed from tree to useable product. This cost ranges from the simple round pole cut from the forest and carried by the builder for immediate use in construction of a building, to the most sophisticated, reconstituted, engineered composite such as oriented strand board. Superimposed on these factors is the transport distance from production point to market place, the regulatory and customary barriers erected along the route and the foreign exchange rates applicable.

We cannot forecast all of these with any degree of confidence so we must look at trends and modify them by some subjective assessment of the underlying factors.

We offer two conclusions on future consumption of Canadian lumber:

- wide boards may not command historical price premiums, since trusses will replace solid beams in many applications and the wider members needed can be made from re-constituted products; and

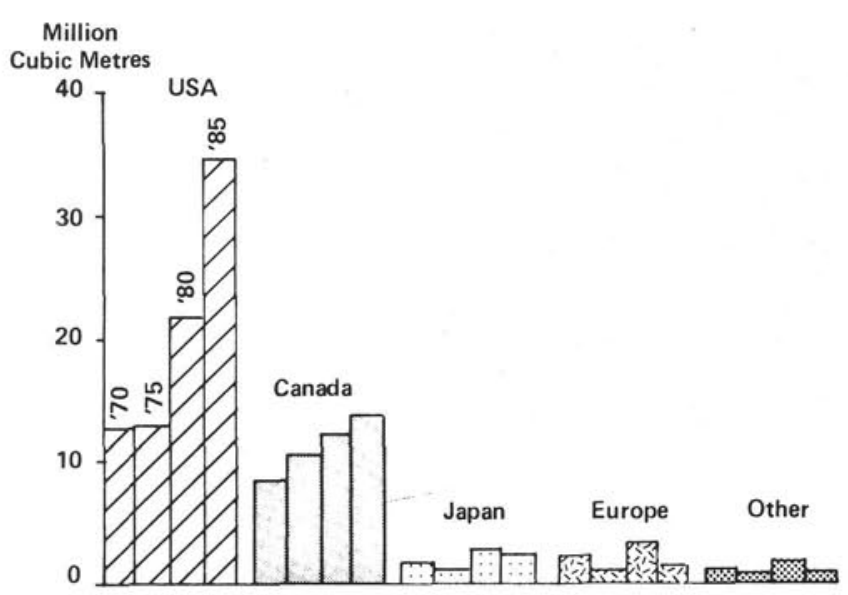

Figure 3. Canadian Lumber Shipment Volumes, 1970 to 1985 Five Year Intervals.

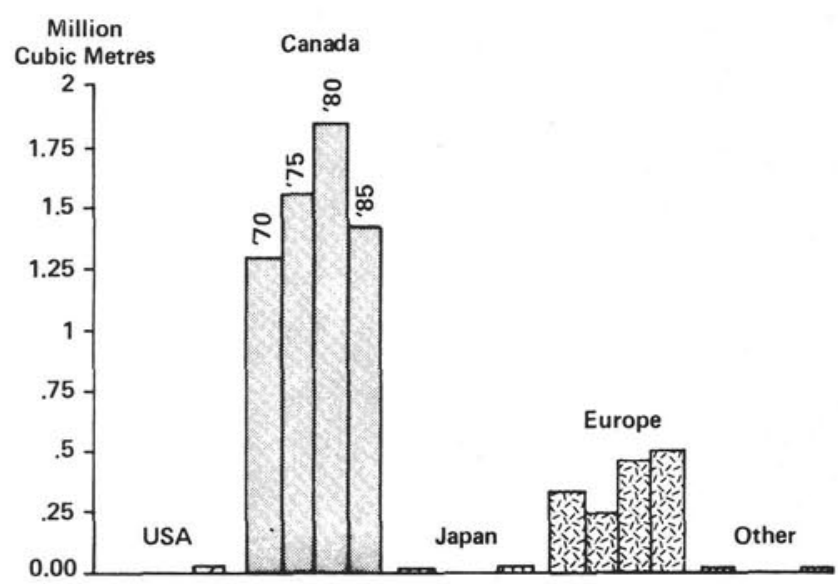

Figure 4. Canadian Plywood Shipment Volumes, 1970 to 1985 Five Year Intervals

- there will be an increasing trend for construction lumber to be sold on a measured strength basis rather than the traditional, visual grades of common species.

Decorative lumber applications are driven by the same factors of supply, degree of modification and transport distance, together with the indefinable "aesthetic appeal". Increased prices will shrink markets by encouraging substitution.

It is in the re-constituted wood products sector that the greatest changes will occur. Products not yet envisaged, incorporating wood and other materials will be introduced. The direction of development in this area is discussed later.

\section{Hardwood Lumber}

Because hardwood lumber is a relatively small part of the Canadian forest sector, (although locally important) and because we on the west coast have little expertise in this area, we only offer the general comment that since Canada has a surplus of hardwood logs, production of hardwood products will tend to increase with attendant trade opportunities. 


\section{Softwood Lumber}

In 1985, COFI completed a world study of softwood lumber demand to the year 2000. The results this are used as the basis for discussion of trends in the major trade flows.

In global terms, lumber consumption is projected to increase slowly, averaging just less than one per cent annually. The trends projected for the various regions of the world are considered below.

\section{USA}

The US ${ }^{1}$ is the largest single country market in the world and consumption is expected to grow at a healthy rate from 1980 to 2000 (see Figure 5). More than half of this projected increase has already occurred. The increases in future demand, which are forecast by COFI, should be tempered with some caution, since demographic studies show that US housing starts in the 1990's may fall. Residential housing is still the biggest single sector of wood consumption in the U.S. and other sectors must pick up any slack and increase as well, if the consumption forecasts are to be realized. Despite increases in domestic production, demand continues to exceed supply and Canada, the biggest exporter of lumber in the world, will provide about one third of US needs.

Recent inventory of the forests of the US south suggest that previous estimates of potential supply from this area may have been optimistic, but any shortfall can be made up by increases from the Pacific Northwest, where large supplies are only constrained by administrative and political decisions: US Forest Service non-declining evenflow policies, environmental restrictions and land allocation agreements.

The actual volume of Canadian softwood lumber shipped to the U.S. will depend on relative exchange rates, costs of production (including wood supply costs) and artificial barriers to trade, but all realistic views of the situation see the Canadian role as remaining most important from the viewpoint of both countries.

\section{Europe (excluding the USSR)}

The European market, mainly the expanded EEC, is currently about the same size as that of the U.S.A. but is not expected to grow significantly over the next 20 years (Figure 6)

Three factors, in addition to the omnipresent exchange rates, tariff and non-tariff barriers could influence the Canadian share of the European market. Several European countries are projecting increases in domestic wood supply, which will make them more self-sufficient in lumber (e.g. United Kingdom, 25\% self-sufficiency by 2000), or gives them greater export potential (e.g. Spain, Sweden). A worst case scenario for air pollution (acid rain) effects on timber supply could see a large additional volume of lumber produced in Europe as salvage operations proceed apace in the next 1015 years. This would effectively dampen the demand for imports. Also, the Europeans have their own "administrative" constraints, which prevent the harvesting of the full, theoretically available, annual cut. The most significant of these is the fragmented tenure of the forest. If a large,

"Note that the North American data is in "nominal" measure c.f. the rest of the world in actual wood volumes. This means that North America data are overstated by up to $25 \%$. For purposes of discussing trends this anomaly is not significant.

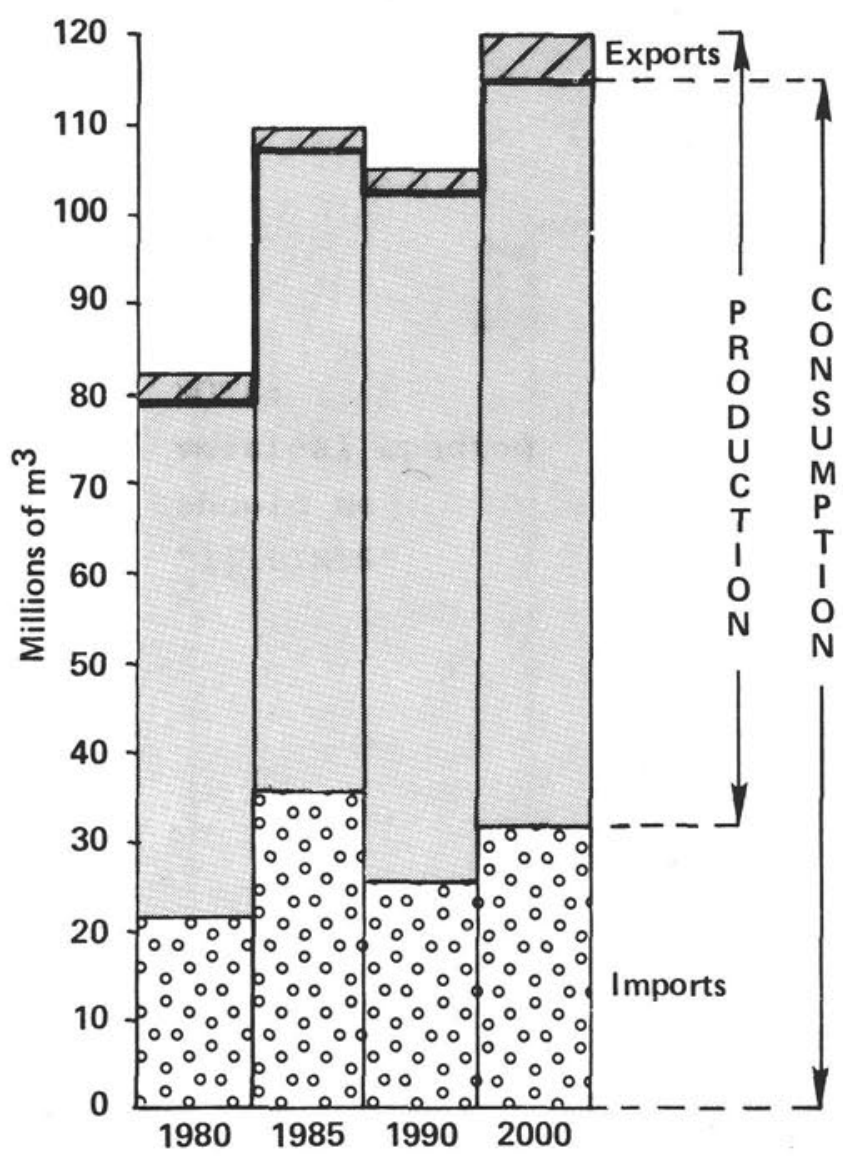

Figure 5. US Softwood Lumber Trade

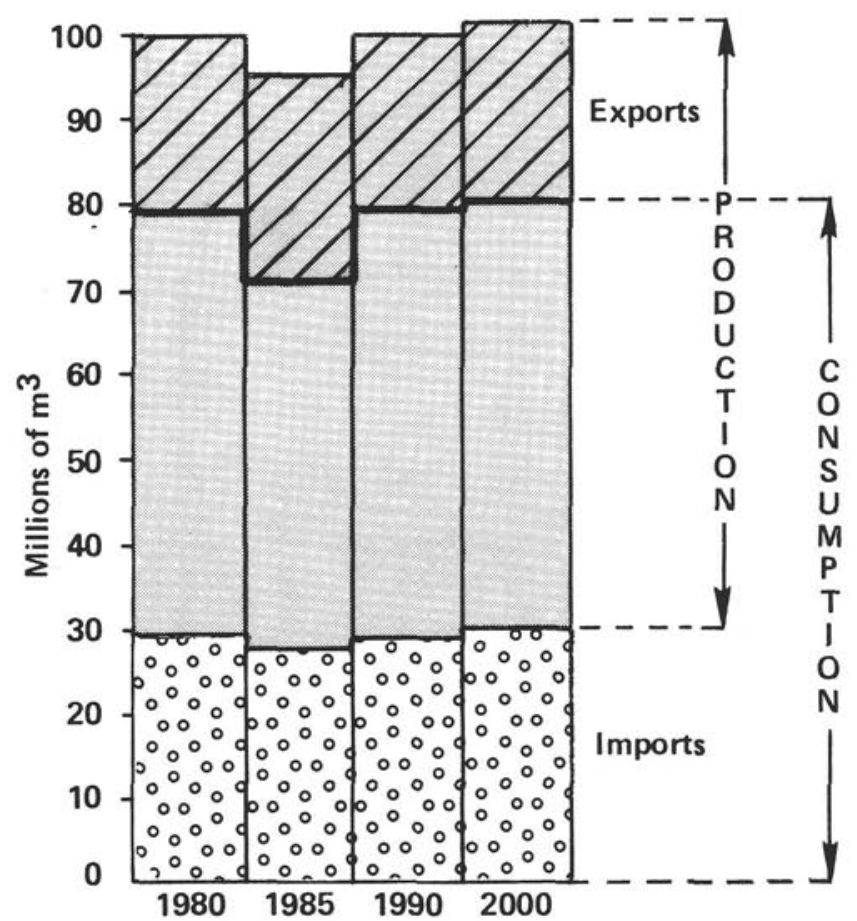

Figure 6. European Softwood Lumber Trade (excl. USSR) 
temporary increase in cut, occasioned by the salvage of forests damaged by air pollution, was followed by an impending, dramatic shortfall, it is conceivable that enabling legislation to tap more fully the available wood supply could be introduced in countries such as France.

The net conclusion is that Europe is unlikely to provide a convenient home for Canadian lumber commodities in quantities much larger than at present. Looming over any prognosis for Europe is the relationship of the North American currencies to those of the EEC and Scandinavia, changes in which can upset any forecast.

\section{USSR}

Because Russian behavior in the lumber business is not governed by normal economic rules, any forecasts are little more than educated guesses. Those from COFI are as likely to be right as any: modest increases in production, consumption and exports to other eastern block countries, with little affect on current trading patterns (Figure 7).

We would suggest, on balance, that the forecasts could be low. The new, far eastern railway and apparent attempts by $\mathrm{Mr}$. Gorbachev to encourage expansion of the domestic economy must be weighed against the depletion of the EuropeanRussian forests and the monolithic intrasigence of the Russian bureaucracy. Increases in Russian production would be more likely to affect Canadian exports to the Pacific Rim than to Europe.

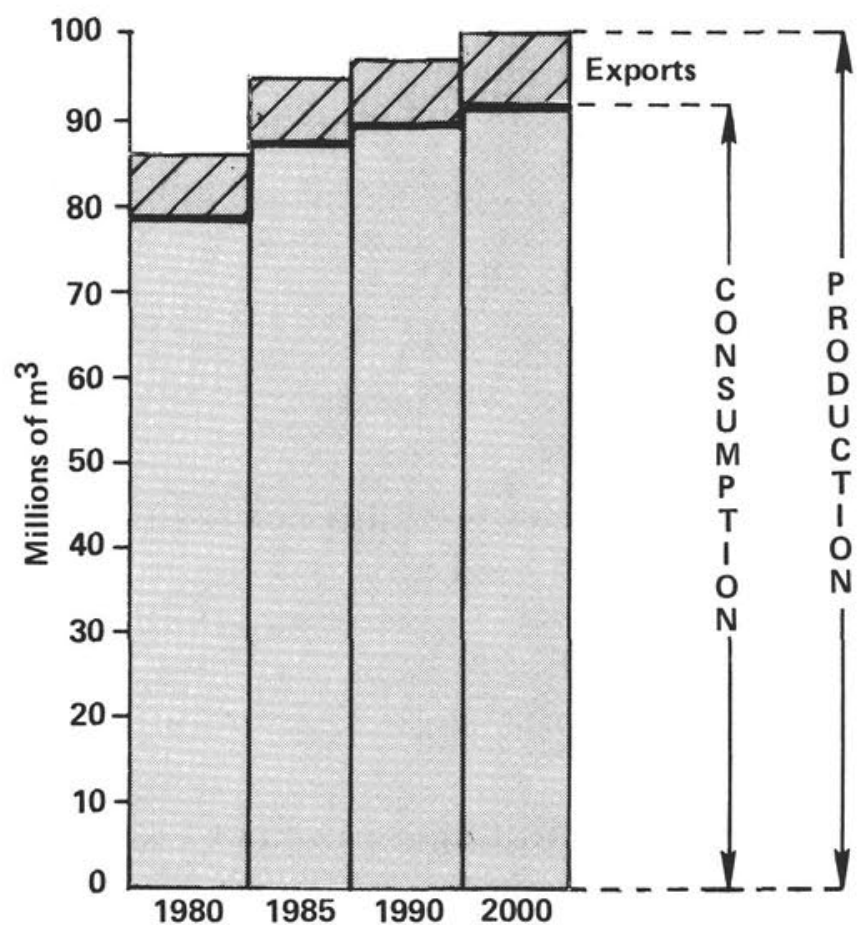

Figure 7. USSR Softwood Lumber Trade

\section{Africa}

Africa imports about half of its consumption, almost all in northern (Mediterranean) Africa (Figure 8). The southern part is almost self-sufficient and South Africa is exporting some softwood lumber.
Projected increases in African demand, while modest, must be tempered. The oil-rich countries' ability to import lumber will be dictated by their oil revenues and priorities for foreign exchange allocation. Barter trade is becoming more important and gives an advantage to suppliers from socialist countries.

Asia

Although Asian softwood lumber consumption in aggregate is not expected to change much over the next 20 years (Figure 9), the pattern of consumption may.

Japanese consumption is projected to fall, together with domestic production (Figure 10). Imports stay fairly steady. The Japanese situation is fraught with options, which lead to different supply-demand balances.

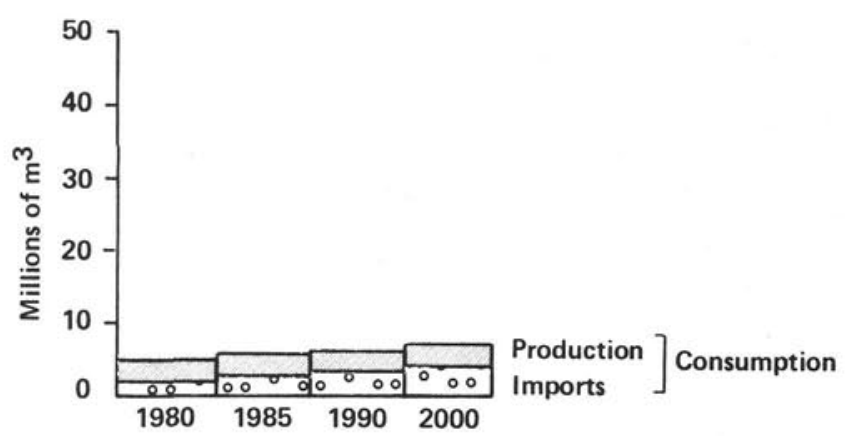

Figure 8. African Softwood Lumber Trade

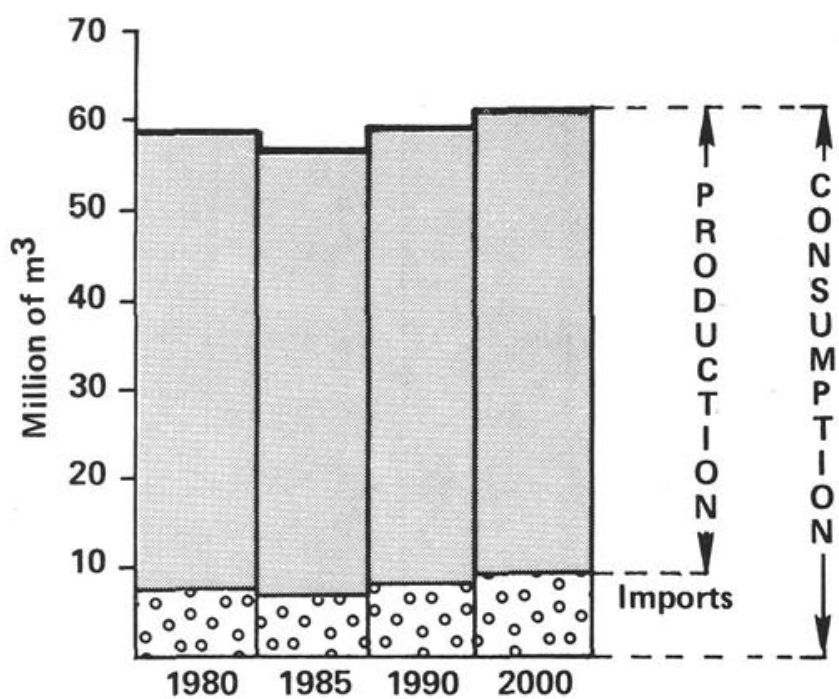

Figure 9. Asian Softwood Lumber Trade

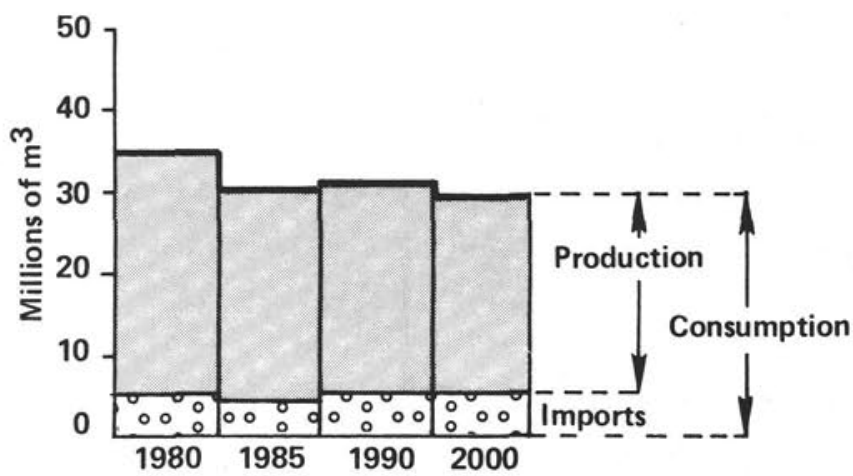

Figure 10. Japanese Softwood Lumber Trade 
These include:

- changes in coniferous log export policy by suppliers (U.S.A, Canada, Chile, New Zealand and U.S.S.R.);

- rate of substitution of conifers for hardwoods may be affected by policies of hardwood producers;

- a devaluation of the yen would make it more attractive to harvest a portion of the potential Japanese cut, currently being stored on the stump, rather than importing; and

- changes in tariff and non-tariff barriewrs to lumber imports.

The COFI forecast is a reasonable compromise.

The Chinese are forecast to increase their lumber imports from practically nothing in 1980 to 2 million $\mathrm{m}^{3}$ in 2000 (Figure 11).

At the same time consumption rises from 13.3 million $\mathrm{m}^{3}$ to 19.6 million $\mathrm{m}^{3}$ and domestic production from 13.3 to 17.6 million $\mathrm{m}^{3}$. There is little doubt that the potential demand for lumber is present in China. Its realization depends on several factors, political and economic:

- rate of industrialization within China. (this is constrained by both infrastructure and economics);

- decisions on the allocation of foreign exchange; and

- log export policies of the supplying countries, in particular the political relationship with the U.S.S.R. as reflected in trade.

If anything we would categorize the COFI forecasts as mildly optimistic.

There are opportunities for Canadian and US Iumber imports into China but to take full advantage of them we shall probably have to tie them to other products. The Chinese would prefer logs to lumber; they have no shortage of labour.

\section{South America}

This market is not large, being comparable with Canada's domestic consumption. But it is forecast to grow at a fair rate (Figure 12). However, South American production of softwood lumber, particularly from Chile and Brazil, is expected to fill most of the increased demand. Canadian exports are unlikely to find a ready destination in South America: they are too expensive to compete with regional supply and the use of wood saves on labour costs, an item that is plentiful and cheap throughout most of the region.

\section{Oceania}

Australia and New Zealand consume only about $1 \%$ of the world softwood lumber supply. They are noted here because they provide examples of two of the emerging competitors for Canada in the incremental softwood lumber trade. See Figure 13 - not different scale from other figures.

Australia is heading towards self-sufficiency in softwoods. Although they will continue to import some special items (Douglas fir and western redcedar lumber is highly prized in the Australian market place) the imported volume will drop. The message here for the Canadian lumber exporter is "niche marketing".

New Zealand already produces much more softwood lumber than it consumes and imports almost none. But by 2000 they have the option to produce almost three times as much as they do at present. This wood, whether in log or lumber form, will be out in the market place looking for a home.
The volume of lumber exports is projected to grow from about $560,000 \mathrm{~m}^{3}$ in 1985 to more than 3 million $\mathrm{m}^{3}$ in 2000. (By comparison Canada exports about 30 million $\mathrm{m}^{3}$.) Countries like New Zealand will be competing with Canada in the next 20 years, albeit with different kinds of lumber.

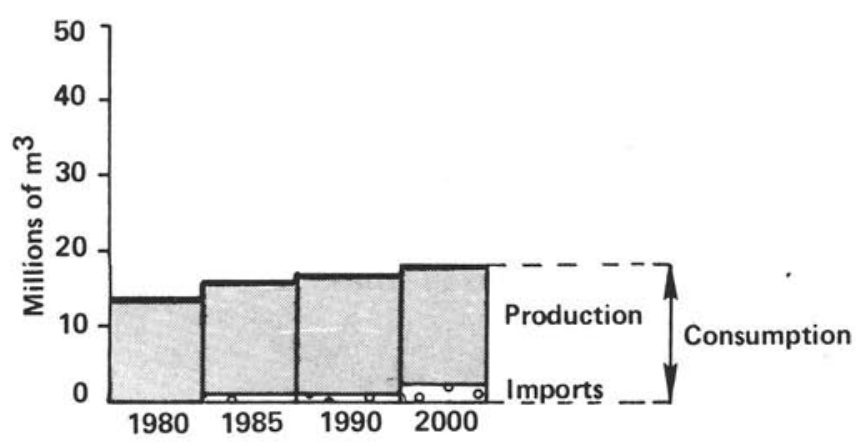

Figure 11. Chinese Softwood Lumber Trade

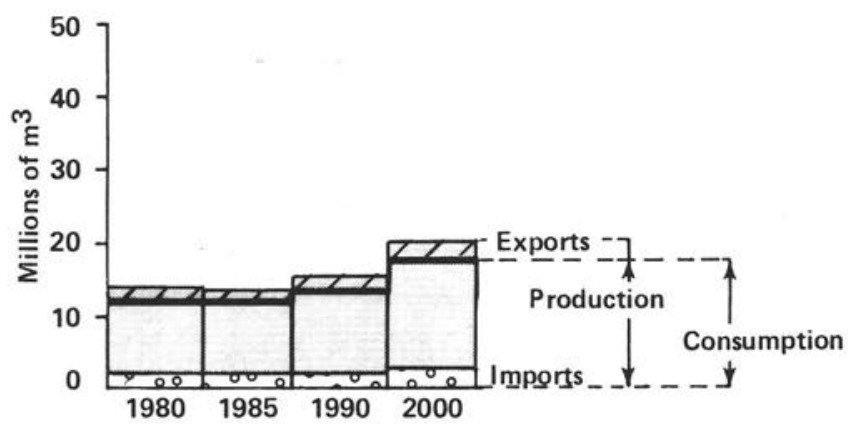

Figure 12. S. American Softwood Lumber Trade

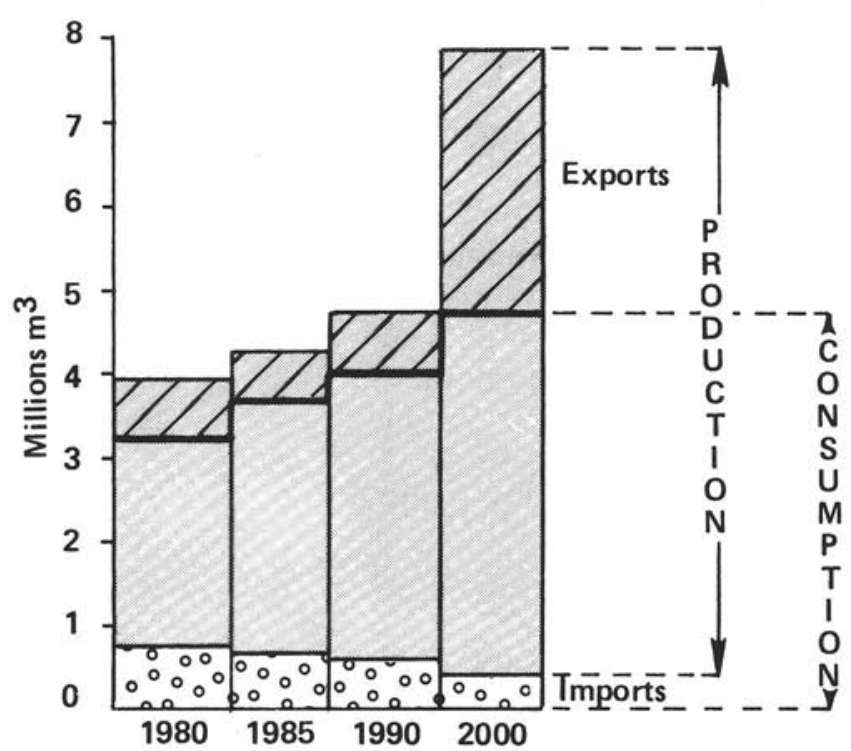

Figure 13. Oceania Softwood Lumber Trade 
Canada

As the largest trader, Canada exports about half of all the softwood lumber traded in the world and is thus vitally interested in the trends discussed above (Figure 14).

On the commodity side there is no shortage of world supply foreseen in the next 20 years, nor probably in the succeeding 30 years.

One aspect of the lumber business has not been discussed: the specialty, decorative trade. In particular the large, show-grown, old growth trees on the BC coast offer a valuable source of such products. The current production of perhaps 2 million $\mathrm{m}^{3}$ per year is only $4 \%$ of Canadian lumber production but its value at about $\$ 190 / \mathrm{m}^{3}$ of product $(\$ 450$ / $\mathrm{Mfom})$ is disproportionately large when compared with the bulk commodity products selling at $\$ 97 / \mathrm{m}^{3}$ ( $\left.\$ 230 / \mathrm{Mfbm}\right)$. Total value today is of the order of $\$ 400$ million. The opportunity to increase this volume is there, as well as to add considerably to its value by further re-manufacturing to produce more completely-finished products.

We would strike a cautionary note on value-added products, which some industry observers have been touting as the panacea for all of our problems. First, "value-added" implies a more completely finished product. There is little benefit in adding $\$ 20$ of value to a product at a cost of $\$ 30$. Second, the markets for value added products require considerable effort and time to develop and are not limitless. A large proportion of our commodity products already have all the value that is going to be added: for example, studs for housing construction. A flood of value-added products into a limited demand markel will just lower the price with the same result as in the first caveat.

The competition for specialty lumber sawn from the old growth BC coastal forest is largely from the US P.N.W. and some tropical hardwoods. In this field, meeting the customers needs and "niche marketing" will be the key to successful trading

\section{Reconstituted Wood Products}

In the ver-changing world of re-constituted wood products (from which we exclude only pulp and paper) the term "wood-based panels" has become out-moded.

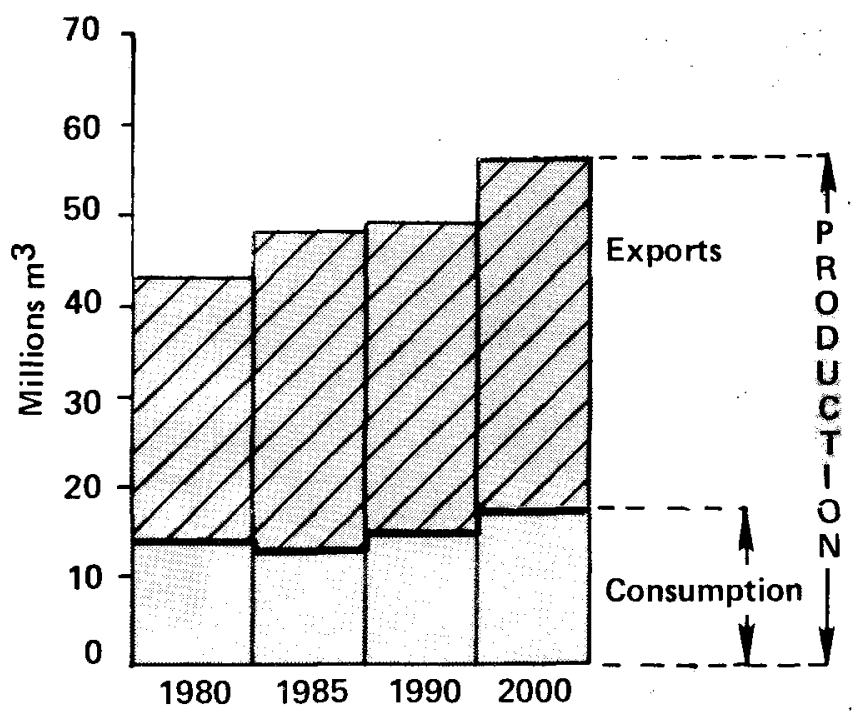

Figure 14. Canadian Softwood Lumber Trade

Figure 15 shows the basic taxonomy involved. Simply combining the elements of wood will give several hundred potentially commercial products, adding non-wood elements we get many thousands. Given this complex base and the continuous development of new products, it is clearly meaningless to talk about long-term trade prospects for presently common products. Rather we shall address the basic issues involved in this development and draw some conclusions.

Like lumber, the composites fall into two use categories: "structural" and "decorative" with a little overlap between them. On the structural side the objective has been to provide equivalent strength to the traditional product at a lower cost of production and/or application. A classic example of this is the progression from wide lumber boards, through plywood, waferboard to oriented strand board (OSB). An OSB product with all the strength characteristics of structural plywood at three-quarters of the cost is now more than conceptual and OSB will undoubtedly replace plywood in many applications over the next 20 years. What will replace OSB? In the

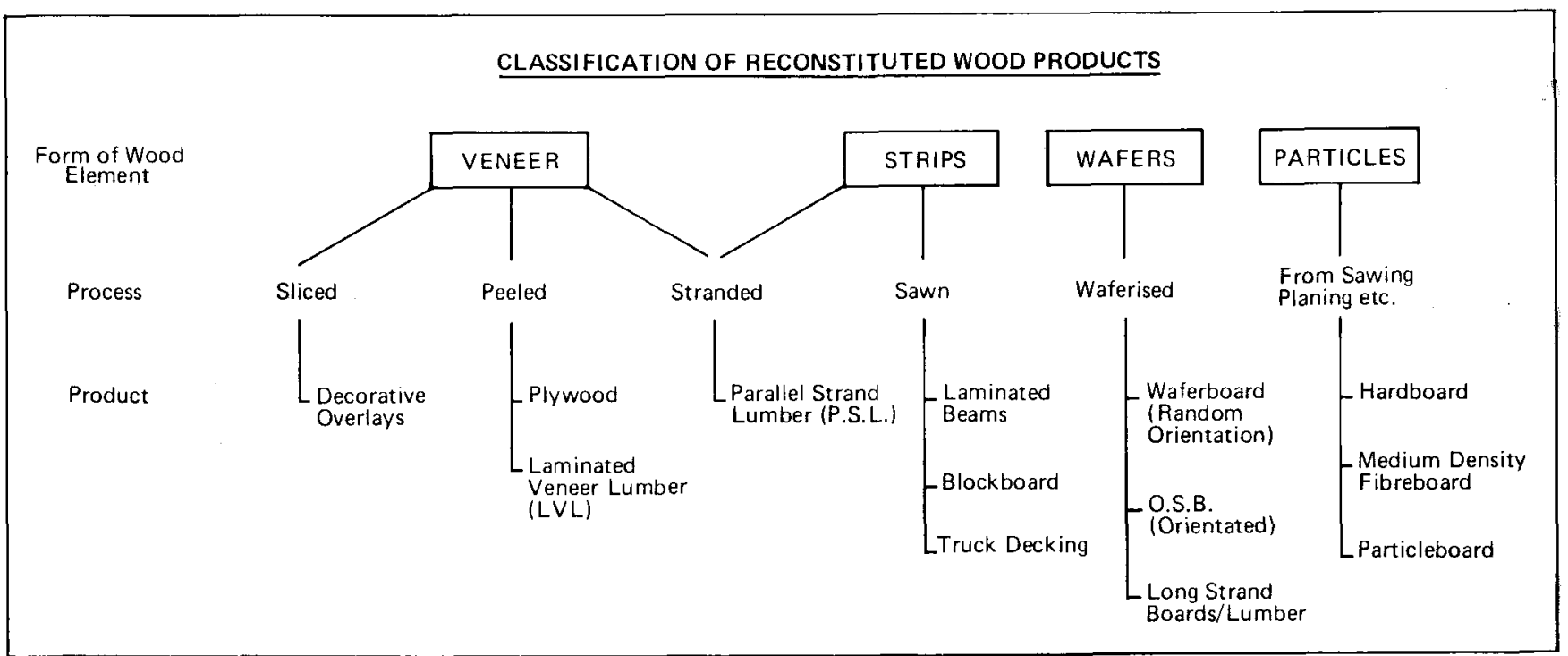

Figure 15. Classification of Reconstituted Wood Products 
waferboard/OSB trade, Canada will lose current market share in the U.S. as domestic production increases. Absolute volumes of exports will not drop.

Composites also substitute for lumber in trusses and progressively more, in engineered wood uses where consistency of performance at predetermined strengths is an important economy measure.

Composites can be made from species less desirable for traditional wood products and from plants that do not grow into trees, e.g. bamboo. Composites can be made from logs of a form unsuitable for traditional products, e.g. small and deformed. Such material is often cheaper than the logs used in traditional products. It may also be a by-product of a higher value production process, e.g. sawdust.

Composites can incorporate materials other than wood (e.g. metals, plastics) to meet specific end use dernands. The options are almost limitless. A little imagination will design you a building with appropriate insulation, fire resistance, plumbing, wiring, heating and strength all incorporated in components that snap together on site.

In the decorative field, overlays of one kind or another on a composite base, can create almost any illusion you choose.

The key factors that drive all this development are:

- specialized market targeting,

- innovative thinking,

- product and process development,

- economic wood supply,

- capital investment (risk capital), and

- location of the markets (transportation cost).

These must be brought together in an economic environment which is favourable to the progression. Because reconstituted products tend to substitute technology, energy and capital for labour, the trend will be towards their production and use in the more industrialized countries of the world.

Canada has opportunities in the composite field; commercial waferboard production was pioneered in this country; market development in the U.S. was done by Canadian industry. Parallel strand lumber is a recent Canadian innovation. But the competition is fierce and the provision of an appropriate economic environment for development is a pre-requisite.

As a relevant adjunct, we would point out that spending on research and development on the whole wood products sector in Canada is at a minimal level.

In rough terms, as a per cent of sales volume:

- solid wood products

- pulp and paper

- chemical industry

$1.0 \%$

*(Research conducted by foreign parent companies)

Unless considerable effort is made in product, process and market research, Canada will tend to be a follower (which in itself is not necessarily bad) and innovations will be largely a matter of good fortune.

\section{Trade Conclusions and Implications}

\section{Lumber}

1. The world demand for softwood lumber will not strain the supply resources to the turn of the century and beyond. Growth in consumption is matched by supply from new and existing forests. This is especially true for commodity items. We are looking at a buyers market. Constant dollar prices for commodities will not rise.

2. Some $70 \%$ or more of Canadian softwood lumber production will continue to be exported.

- the U.S. will still take the lions share of our lumber exports (perhaps 75\%);

- major markets in Japan and Europe will not readily accept any increase in Canadian commodity lumber exports due to low or no growth and adequate supplies;

- South American and African markets, although expanding, are not large and will accept little additional Canadian lumber; and

- the Pacific Rim countries (except Japan), in particular China, seem to offer the best opportunity for receipt of incremental, Canadian, commodity lumber supply.

3. Despite the trend to more value-added products Canada will still be primarily an exporter of commodities.

4. Innovative marketing will be required together with increased productivity and strict cost controls to maintain the Canadian position in lumber exports

5. Opportunities in lumber specialties will be available to the innovative, market-niche orientated entrepreneur.

6. Exchange rate changes and artificial barriers to international trade can render all lumber trade forecasts invalid.

\section{Reconstituted Wood Products}

1. Continual development of new products will occur. These will have equivalent strength to the traditional products at a lower cost of production and/or application.

2. Trends in trade will be dictated by the ability of individual corporations or countries to be inventive and invest in:

- product research,

- process research,

- market research

- new plants for the new products, and

- market development.

3. Waferboard/OSB replacing plywood in many applications is just one example of evolution in the wood products trade.

4. Reconstituted products, which can be engineered to match many specialized end uses, will tend to have the greatest use in the most industrialized regions of the world. Canada, being adjacent to the single largest potential market, is in a position to take advantage of opportunities, but a much greater research and development effort in specialized products will be needed to provide the basis for an assured position. 


\section{Present Forest Management and Future Trade in Solid Wood Products}

Media rhetoric to the contrary, our forest management practices of today have little direct effect on the wood supply of the next 20 years and probably, the next 50 years. Trees take a long time to reach merchantable size. But there is an important, indirect effect of today's forest renewal and subsequent management. Under the sustained yield policy, adopted by most of the forest managers in Canada, forest renewal today can permit harvesting today at a rate that need not be lowered in the future, provided the present resources and age class distribution are adequate.

The world is not likely to be short of wood at the time when today's new forests are ready for harvesting. But new trade opportunities will still be available.

Given that Canada has an inherent competitive disadvantage globally because of its relatively low tree growth rates, we should grow trees that permit the realization of other advantages; for example:

- the slower growth rates may be aesthetically desirable in solid wood products used decoratively;

- the strength/weight ratio of our major species in lumber;

- the small core of juvenile wood in our slow grown trees; and

- the distinctive colour of certain species

Trees need not be too big for structural applications of the lumber milled from them, but, given the highly competitive trade forecasts, they must be delivered to the mills at a competitive cost.

The demand for and form of the solid wood products of the future are impossible to forecast. We must trade on the inherent advantages of wood and the special qualities of our trees species

\section{Recommendations}

Given the conclusions:

- forestry in the 21 st century is global in scope;

- Canada must export forest products;

- no increase in real prices for forest commodities;

- trend to more value-added; and

- need for productivity improvement;

all of our recommendations relate to the development of an industrial strategy for the forest sector that is directed towards the enhancement of Canada's competitive position in the global trade picture. This should be achieved through the untrammeled application of elementary economics in the market place:
1. Tax incomes not assets to provide government services, e.g. minimize real property taxes.

2. Set tax rates at levels that permit the accretion of profits and establish tax policies that encourage re-investment so that much needed capital investments can be made.

3. In view of the present desperate need for capital investment in the industry and the accumulated Capital Cost Allowances, modify the tax regulations to permit the immediate monetisation of these funds for investment.

4. Government must not subsidize capital investment by outright grants or interest free loans. These interferences in the economy at best give one company an unfair advantage over another to the detriment of the latter. At worst they extend the life of "losers" with a resultant exacerbation of the oversupply situation. This keeps markets soft and hurts the whole sector

5. Negotiate internationally with a view to continued lowering and eventual elimination of trade barriers.

6. Permit log exports at the discretion of the owners. This will increase log prices and provide the economic justification for more intensive forest management.

7. Governments' role in the support of research and development should be strengthened.

In particular, we require some realistic estimates of the potential benefits of forest management in the various regions of the country, both material (growth response to treatment) and financial. Armed with these, some rational decisions on the extent and intensity of forest management can be made. These, in turn, will point the direction for the manufacturing side of the forest sector.

8. Industry must work together with governments to develop market niches appropriate to our products in all regions of the world.

9. Labour's demands on the forest industry must recognize the global nature of the forest sector, the need to be cost competitive, the need for profits to permit investment in productivity improvements. With this recognition, the forest industry can grow in value, if not in volume and labour will be able to maintain a good standard of living. 